\title{
CONNECTIVE TISSUE DISEASES: FOCUS ON MICROCIRCULATORY BED
}

\author{
*O.I. Zarudna, I.K. Venher, A.V. Dovbush \\ I. HORBACHEVSKY TERNOPIL NATIONAL MEDICAL UNIVERSITY, TERNOPIL, UKRAINE
}

\begin{abstract}
Background. A microcirculatory bloodstream is a target, source and reason of the pathological process in patients with systemic connective tissue diseases.

Objectives. This study is focused on meta-analyses of biopsy material of skin flaps harvested from patients' fingers to identify specific morphological changes.

Methods. A retrospective analysis of the medical records of 39 examinees with systemic sclerosis (SSC), 45 with Systemic Lupus Erythematosus (SLE), and 45 with rheumatoid arthritis (RA) was performed. The condition of peripheral hemodynamics was examined with longitudinal rheovasography of arms and legs. Endothelin-1 (ET1) concentration was evaluated by immunoenzymatic method. We assessed other results of clinical and laboratory tests to compare them with morphological changes of the microcirculatory bed.

Results. Most patients involved suffered from abnormal peripheral hemodynamics. It was revealed that kidneys, lungs or heart were damaged more frequently in the patients with peripheral blood circulation disorders, which were the most significant in the patients with SSC $(p<0.05)$. Disorders of peripheral blood flow were exacerbated in case of lengthening of the disease course. Concentration of ET1 was relevantly higher in the patients with peripheral blood flow disorders. Number of pathologic capillaries was the highest in the SSC patients.

Conclusions. In terms of integral estimation, extremely significant changes of microcirculatory bloodstream were evidenced in the patients with SSc. However, some morphometric peculiarities were revealed in the patients without peripheral blood flow disorders. Thus, normal rheovasography did not exclude any microcirculation disorders.
\end{abstract}

KEY WORDS: microcirculation; systemic lupus erythematosus (SLE); systemic sclerosis (SSc); rheumatoid arthritis (RA); biopsy; rheovasography.

\section{Introduction}

Manifestations of systemic connective tissue diseases are very diverse. However, one thing they all have in common is vasculitis/ vasculopathy that results in systematicity and development of permanent malfunctioning of body organs and systems. Several studies show that patients with systemic lupus erythematosus (SLE), systemic sclerosis (SSc), and rheumatoid arthritis (RA) experience such symptoms as Raynaud syndrome, livedo reticularis, recurrent thrombophlebitis, digital vasculitis, capillaritis of palms and soles, etc. Among the manifestations listed above the most common sign is Raynaud syndrome that is characterized by cascade disruption of microcirculation: destruction of vascular endothelium, capillary basement membrane reduplication, intimal proliferation of smooth muscle cells with collagen hyperproduction and predisposition to vasoconstriction, vascular wall thickening with luminal occlusion,

*Corresponding author: Olga Zarudna, Department of Clinical Immunology, Allergology and General Patients' Care, I. Horbachevsky Ternopil National Medical University, 1 Maidan Voli, Ternopil, 46001.

E-mail: zarudna@tdmu.edu.ua. which is manifested by generalized clinical symptoms. Meanwhile, endothelium is a target, source and reason of the pathological process. It becomes a receptive field for binding of circulating immunoglobulins, immune complexes, a complement and attacks of sensitized T-lymphocytes. It itself produces vascular endothelial growth factor, endothelin 1, etc. Similar findings are presented in the literature $[1,2,3,4]$.

Numerous studies have been conducted in order to identify noninvasive methods of studying microcirculatory bloodstream and detect specific pathological characteristics in favour of one or another connective tissue disease to help confirm a diagnosis. Consequently, the method of nailfold videocapillaroscopy is relevant $[5,6,7]$. Moreover, the results of nailfold videocapillaroscopic examination are included into diagnostic classification by EULAR criteria of systemic sclerosis [5], indicating their high specificity and sensitivity.

For an overall assessment of capillaroscopic pattern, the following indicators are used: capillary length, intercapillary distance, loop diameter, internal diameter, capillary width, 
apex width, venous limb, arterial limb [7]. Data analysis shows typical changes, for example, SSc: giant capillaries, loss of capillaries with areas of avascularisation, ramified capillaries with pathological neoangiogenesis and severe derangement of capillary structure [5]. Nailfold capillaroscopic form changes are less symptomatic in cases of other diseases, for example in SLE. According to the literature concerning the above-mentioned pathology, they are present in $30-75 \%$ of cases. SSc (in contrast to SLE) characteristically reveals these changes that occur in $99 \%$ of cases at various stages [5, $6]$. The most frequent alterations in the patients with SLE include increased tortuosity, elongated loops, and meandering bizarre loops [5]. The patients with RA are reported to have increased capillary tortuosity and prominent, clearly visible subpapillary venous plexus [5]. At the same time, according to the study of autoimmune processes, in some pathological conditions, correlation between the rate of biologically active substances and results of capillaroscopy was revealed. For example, in cases of SLE a relation between concentration of endothelin-1 (ET-1) and angioscopic characteristics of microcirculatory bloodstream (MCB) was found [8]. Meanwhile, increase in anti-endothelial antibody titre in cases of SSc was present in $22-86 \%$ of cases and combined primarily with lung damage and peripheral vascular bed [4].

A few researches describe the results of immune histochemical tests that allows establishing that CD20+, B-lymphocytes, macrophagocytes and dendritic cells, Ig G, A, M, and a complement in the form of deposits along elastic membrane of a vascular wall prevail among the cells that infiltrate a vessel wall [9].

The revealed morphological abnormalities and immunological disorders in systemic diseases of connective tissue combined with endothelial dysfunction and coagulation system disorders create favourable conditions for development of severe systemic complications.

The research is aimed at a retrospective study of morphological condition of a peripheral vascular bed in the patients with $\mathrm{SLE}, \mathrm{SSc}$, and RA to compare morphological changes with clinical and laboratory data.

\section{Methods}

Retrospective analysis of the medical records of 129 patients with rheumatic diseases was performed: 39 were diagnosed with SSc, 45 with SLE, and 45 - with RA (all were the patients of Ternopil University Hospital, Department of
Rheumatology, 2001-2004). The statistical analysis revealed a typical situation for this category of diseases - predominance of women $(86.05 \%)$ of fertile age. The average duration of the disease was $8.14 \pm 0.53$ years. The archive of biopsy material of skin flaps harvested from patients' fingers was reviewed that allowed morphometric analysis. The decision for biopsy was made by a rheumatologist during the treatment at the Department of Rheumatology. For histological studies, pieces of skin were fixed in $10 \%$ neutral formalin solution. Subsequent processing of the material followed by embedment in paraffin blocks was carried out by a conventional technique. The sections obtained by a sliding microtome were stained with hematoxylin-eosin. The histological specimens were studied using the optical microscope SEO SCAN and images were made with the Vision CCD Camera with a histological image display system. The condition of peripheral hemodynamics was examined by longitudinal rheovasography of forearm and legs by means of software-hardware complex of automated analysis USRH-1 ("УСРГ-01"). In the process of rheovasographic analysis the following medical parameters were estimated: the regularity of pulse waves, their appearance- upward and downward gradients, the type of a top (apex), extent of incisura, presence of additional waves, their localization on the descending part of a curve. The following measurements were analysed:

As - percussion systolic wave amplitude of a rheogram, Ohm;

RI - rheographic index, that measures a magnitude of pulse volume, in other words a systolic flow; that is a correlation of a variable and a constant dimensions of impedance of the researched area, namely, a percussion wave of a rheogram and calibration impulse magnitude, relative units (RU);

$\mathrm{Ai}$ - interval between the isoline and incisures on the descending part of a curve, Ohm;

DI - dicrotic index, which reflects the condition of the tone of arteries and precapillary vessels, \%.

The main indicator that was used for analysis was a rheographic index that measured the magnitude of pulse volume that was a systolic flow defined by a ratio of a percussion wave of a rheogram and calibration impulse magnitude, relative units ( $R U)$.

The condition of endothelium was examined in terms of one of the main integral indicators of its functional capacity, i.e. ET1. The contents of ET1 were determined using an immuno- 
enzymatic method, which was based on the principle of competitive immunoenzymatic analysis, involving a reagent kit Peninsula Laboratories Inc. (USA).

The severity of inflammation was determined by erythrocyte sedimentation rate (degree 1 - ESR $<20 \mathrm{~mm} / \mathrm{hr}$, degree 2 - ESR 20-40 mm/hr, degree 3 - ESR $>40 \mathrm{~mm} / \mathrm{hr}$ ).

All case histories contained informed consents for the research. The study was conducted in accordance with the Declaration of Helsinki. The Protocol was approved by the Committee on Bioethics of I. Horbachevsky Ternopil National Medical University.

Statistical processing of the research results was performed by parametric analysis and nonparametric analysis using the Student's t-test and Mann-Whitney U-test by means of software package Microsoft EXCEL 5.0 and Statistica 10 (StatSoft). $p$ values lower than 0.05 were considered to be statistically significant.

\section{Results}

All cases were divided into two groups according to the state of peripheral hemodynamics, which was examined using longitudinal rheovasography of forearm and legs.
The majority of patients, the model participants of the research, had abnormal peripheral hemodynamics (group 2). The ratio of the above-mentioned patients to the patients with normal peripheral hemodynamic parameters (group 1) was 5.1:1.0. Clinical assessment of the involved patients is presented in Table 1.

Assessment of peripheral hemodynamics allowed revealing significant changes in indices of longitudinal rheovasography of forearms and legs (Table 2).

Morphometric analysis of skin biopsy was conducted in 26 model patients (Table 3, Table 4).

Biopsy results of the patients with different nosology and peripheral blood circulation disorders are presented at Figures 1, 2, and 3.

Notably, microscopic examination revealed that general architectonics of vessel walls was not damaged. Visible hyperplasia of endotheliocytes in all categories of patients was also evidenced, which may be treated as an adaptive mechanism in cases of blood circulation disorders.

The results of patients' blood tests for concentration of ET1 (Table 5) pointed to its extremely high content in the patients with peripheral blood circulation disorders in contrast to donors' indices.

Table 1. Clinical Assessment of the Patients with/without peripheral blood circulation disorders

\begin{tabular}{|c|c|c|c|c|c|}
\hline & \multirow{3}{*}{ Indicant } & \multicolumn{4}{|c|}{ Patients } \\
\hline & & \multicolumn{2}{|c|}{$\begin{array}{c}\text { with normal peripheral } \\
\text { hemodynamic parameters } \\
\left.\text { ( } 1^{\text {st }} \text { group }\right)\end{array}$} & \multicolumn{2}{|c|}{$\begin{array}{c}\text { with abnormal peripheral } \\
\text { hemodynamics } \\
\left(2^{\text {nd }} \text { group }\right)\end{array}$} \\
\hline & & Absolute numbers & $\%$ & Absolute numbers & $\%$ \\
\hline & $\begin{array}{l}\text { Age (years): } \\
\text { under } 20 \\
20-44 \\
45-59 \\
60 \text { and above } \\
\end{array}$ & $\begin{array}{l}3 \\
9 \\
5 \\
4\end{array}$ & $\begin{array}{l}2.3 \\
6.9 \\
3.9 \\
3.1\end{array}$ & $\begin{array}{c}4 \\
53 \\
38 \\
13\end{array}$ & $\begin{array}{l}3.1 \\
41.1 \\
29.5 \\
10.1\end{array}$ \\
\hline & \begin{tabular}{|l|} 
Males \\
Females
\end{tabular} & $\begin{array}{c}6 \\
15\end{array}$ & $\begin{array}{c}4.7 \\
11.6\end{array}$ & $\begin{array}{l}12 \\
96\end{array}$ & $\begin{array}{r}9.3 \\
74.4\end{array}$ \\
\hline & $\begin{array}{l}\text { SLE } \\
\text { SSC } \\
\text { RA }\end{array}$ & $\begin{array}{c}9 \\
1 \\
11\end{array}$ & $\begin{array}{l}6.9 \\
0.8 \\
8.5\end{array}$ & $\begin{array}{l}36 \\
38 \\
34\end{array}$ & $\begin{array}{l}27.9 \\
29.5 \\
26.4\end{array}$ \\
\hline \multirow{5}{*}{ 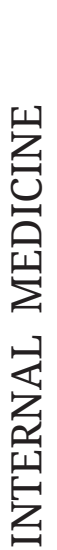 } & $\begin{array}{l}\text { Activity of the } 1^{\text {st }} \text { degree } \\
\text { Activity of the } 2^{\text {nd }} \text { degree } \\
\text { Activity of the } 3^{\text {rd }} \text { degree }\end{array}$ & $\begin{array}{c}2 \\
15 \\
4\end{array}$ & $\begin{array}{c}1.6 \\
11.6 \\
3.1\end{array}$ & $\begin{array}{l}52 \\
41 \\
15\end{array}$ & $\begin{array}{l}40.3 \\
31.8 \\
11.6\end{array}$ \\
\hline & $\begin{array}{l}\text { Duration of a disease }<1 \mathrm{yr} \\
\text { Duration of a disease } 1-5 \mathrm{yrs} \\
\text { Duration of a disease } 5-10 \mathrm{yrs} \\
\text { Duration of a disease }>10 \mathrm{yrs}\end{array}$ & $\begin{array}{l}3 \\
6 \\
5 \\
7\end{array}$ & $\begin{array}{l}2.3 \\
4.7 \\
3.9 \\
5.4\end{array}$ & $\begin{array}{l}10 \\
38 \\
30 \\
30\end{array}$ & $\begin{array}{c}7.8 \\
29.5 \\
23.2 \\
23.2\end{array}$ \\
\hline & \begin{tabular}{|l|} 
Kidney damage \\
No kidney damage
\end{tabular} & $\begin{array}{c}6 \\
15\end{array}$ & $\begin{array}{c}4.7 \\
11.6\end{array}$ & $\begin{array}{l}28 \\
80\end{array}$ & $\begin{array}{l}21.7 \\
62.0\end{array}$ \\
\hline & $\begin{array}{l}\text { Cardiac involvement } \\
\text { No cardiac involvement }\end{array}$ & $\begin{array}{c}7 \\
14\end{array}$ & $\begin{array}{c}5.4 \\
10.9\end{array}$ & $\begin{array}{l}37 \\
71\end{array}$ & $\begin{array}{l}28.7 \\
55.0\end{array}$ \\
\hline & $\begin{array}{l}\text { Lung damage } \\
\text { No lung damage }\end{array}$ & $\begin{array}{c}5 \\
16\end{array}$ & $\begin{array}{c}3.9 \\
12.4\end{array}$ & $\begin{array}{l}23 \\
85\end{array}$ & $\begin{array}{l}17.8 \\
65.9\end{array}$ \\
\hline
\end{tabular}


Table 2. Indices of peripheral blood circulation in the patients of group 2 (with peripheral hemodynamic disorders)

\begin{tabular}{|c|c|c|c|c|c|c|c|c|c|}
\hline \multirow{2}{*}{\multicolumn{2}{|c|}{ Indices }} & \multicolumn{4}{|c|}{ Forearms } & \multicolumn{4}{|c|}{ Lower legs } \\
\hline & & \multirow{2}{*}{$\begin{array}{c}\begin{array}{c}\text { As, } \\
\text { Ohm }\end{array} \\
0.123 \pm \\
0.002 *\end{array}$} & \multirow{2}{*}{$\begin{array}{c}\text { RI, } \\
\text { RU }\end{array}$} & \multirow{2}{*}{$\begin{array}{c}\begin{array}{c}\mathrm{Ai}, \\
\mathrm{Ohm}\end{array} \\
0.090 \pm \\
0.002^{*}\end{array}$} & \multirow{2}{*}{$\begin{array}{c}\begin{array}{c}\text { DI, } \\
\%\end{array} \\
73.41 \pm \\
0.08 *\end{array}$} & \multirow{2}{*}{$\begin{array}{c}\begin{array}{c}\text { As, } \\
\text { Ohm }\end{array} \\
0.147 \pm \\
0.003 *\end{array}$} & \multirow{2}{*}{$\begin{array}{c}\begin{array}{c}\text { RI, } \\
\text { RU }\end{array} \\
1.47 \pm \\
0.03 *\end{array}$} & \multirow{2}{*}{$\begin{array}{c}\begin{array}{c}\mathrm{Ai}, \\
\mathrm{Ohm}\end{array} \\
0.105 \pm \\
0.002\end{array}$} & \multirow{2}{*}{$\begin{array}{c}\begin{array}{c}\text { DI, } \\
\%\end{array} \\
71.58 \pm \\
0.08 *\end{array}$} \\
\hline $\begin{array}{l}\text { Duration } \\
\text { of disease }\end{array}$ & $<1 \mathrm{yr}, \mathrm{n}=10$ & & & & & & & & \\
\hline & $\begin{array}{c}>1-5 \text { yrs, } \\
n=38\end{array}$ & $\begin{array}{l}0.091 \pm \\
0.002 *\end{array}$ & $\begin{array}{l}0.91 \pm \\
0.02 *\end{array}$ & $\begin{array}{c}0.075 \pm \\
0.002\end{array}$ & $\begin{array}{l}82.24 \pm \\
0.06 *\end{array}$ & $\begin{array}{l}0.145 \pm \\
0.002 *\end{array}$ & $\begin{array}{l}1.45 \pm \\
0.02 *\end{array}$ & $\begin{array}{l}0.116 \pm \\
0.002 *\end{array}$ & $\begin{array}{l}80.24 \pm \\
0.03 *\end{array}$ \\
\hline & $\begin{array}{c}>5-10 \text { yrs } \\
n=30\end{array}$ & $\begin{array}{l}0.087 \pm \\
0.003 *\end{array}$ & $\begin{array}{l}0.87 \pm \\
0.03 *\end{array}$ & $\begin{array}{c}0.074 \pm \\
0.002\end{array}$ & $\begin{array}{l}84.98 \pm \\
0.08 *\end{array}$ & $\begin{array}{l}0.127 \pm \\
0.003 *\end{array}$ & $\begin{array}{l}1.27 \pm \\
0.03 *\end{array}$ & $\begin{array}{l}0.106 \pm \\
0.003 *\end{array}$ & $\begin{array}{l}83.49 \pm \\
0.04 *\end{array}$ \\
\hline & $\begin{array}{c}>10 \mathrm{yrs}, \\
\mathrm{n}=30\end{array}$ & $\begin{array}{l}0.085 \pm \\
0.002 *\end{array}$ & $\begin{array}{l}0.85 \pm \\
0.02 *\end{array}$ & $\begin{array}{l}0.074 \pm \\
0.001\end{array}$ & $\begin{array}{l}87.18 \pm \\
0.05^{*}\end{array}$ & $\begin{array}{l}0.114 \pm \\
0.003 *\end{array}$ & $\begin{array}{l}1.14 \pm \\
0.03 *\end{array}$ & $\begin{array}{l}0.096 \pm \\
0.002\end{array}$ & $\begin{array}{c}86.26 \pm \\
0.04 *\end{array}$ \\
\hline \multirow[t]{3}{*}{ Disease } & $\begin{array}{l}\mathrm{SLE}, \\
\mathrm{n}=37\end{array}$ & $\begin{array}{l}0.109 \pm \\
0.002 *\end{array}$ & $\begin{array}{l}1.09 \pm \\
0.02 *\end{array}$ & $\begin{array}{l}0.083 \pm \\
0.002 *\end{array}$ & $\begin{array}{c}75.79 \pm \\
0.05 *\end{array}$ & $\begin{array}{l}0.130 \pm \\
0.002 *\end{array}$ & $\begin{array}{l}1.30 \pm \\
0.02 *\end{array}$ & $\begin{array}{l}0.108 \pm \\
0.008 *\end{array}$ & $\begin{array}{l}83.39 \pm \\
0.04 *\end{array}$ \\
\hline & $\begin{array}{l}\mathrm{SSC} \\
\mathrm{n}=37\end{array}$ & $\begin{array}{l}0.082 \pm \\
0.002 *\end{array}$ & $\begin{array}{l}0.84 \pm \\
0.02 *\end{array}$ & $\begin{array}{c}0.072 \pm \\
0.002\end{array}$ & $\begin{array}{l}85.73 \pm \\
0.08 *\end{array}$ & $\begin{array}{l}0.113 \pm \\
0.004 *\end{array}$ & $\begin{array}{l}1.13 \pm \\
0.04 *\end{array}$ & $\begin{array}{c}0.095 \pm \\
0.003\end{array}$ & $\begin{array}{l}84.41 \pm \\
0.06 *\end{array}$ \\
\hline & $\begin{array}{c}\mathrm{RA}, \\
\mathrm{n}=34\end{array}$ & $\begin{array}{l}0.089 \pm \\
0.002 *\end{array}$ & $\begin{array}{l}0.89 \pm \\
0.02 *\end{array}$ & $\begin{array}{c}0.070 \pm \\
0.002\end{array}$ & $\begin{array}{l}79.06 \pm \\
0.06 *\end{array}$ & $\begin{array}{l}0.122 \pm \\
0.003 *\end{array}$ & $\begin{array}{l}1.22 \pm \\
0.03 *\end{array}$ & $\begin{array}{c}0.099 \pm \\
0.003\end{array}$ & $\begin{array}{l}81.11 \pm \\
0.03 *\end{array}$ \\
\hline \multirow{3}{*}{$\begin{array}{l}\text { Activity } \\
\text { of the } \\
\text { inflam- } \\
\text { matory } \\
\text { process }\end{array}$} & $\begin{array}{c}1^{\text {st }} \text { degree, } \\
n=52\end{array}$ & $\begin{array}{l}0.095 \pm \\
0.002 *\end{array}$ & $\begin{array}{l}0.95 \pm \\
0.02 *\end{array}$ & $\begin{array}{l}0.080 \pm \\
0.002 *\end{array}$ & $\begin{array}{l}84.15 \pm \\
0.05 *\end{array}$ & $\begin{array}{l}0.121 \pm \\
0.004 *\end{array}$ & $\begin{array}{l}1.21 \pm \\
0.04 *\end{array}$ & $\begin{array}{c}0.099 \pm \\
0.002\end{array}$ & $\begin{array}{l}81.60 \pm \\
0.09 *\end{array}$ \\
\hline & $\begin{array}{c}2^{\text {nd }} \text { degree, } \\
n=41\end{array}$ & $\begin{array}{l}0.095 \pm \\
0.003 *\end{array}$ & $\begin{array}{l}0.95 \pm \\
0.03 *\end{array}$ & $\begin{array}{l}0.080 \pm \\
0.002 *\end{array}$ & $\begin{array}{l}84.17 \pm \\
0.05^{*}\end{array}$ & $\begin{array}{l}0.113 \pm \\
0.002 *\end{array}$ & $\begin{array}{c}1.13 \\
0.02 *\end{array}$ & $\begin{array}{c}0.095 \pm \\
0.002\end{array}$ & $\begin{array}{l}84.15 \pm \\
0.04 *\end{array}$ \\
\hline & $\begin{array}{c}3^{\text {rd }} \text { degree, } \\
n=15\end{array}$ & $\begin{array}{l}0.105 \pm \\
0.005 *\end{array}$ & $\begin{array}{l}1.05 \pm \\
0.05 *\end{array}$ & $\begin{array}{c}0.080 \pm \\
0.004\end{array}$ & $\begin{array}{l}75.52 \pm \\
0.07 *\end{array}$ & $\begin{array}{l}0.138 \pm \\
0.002 *\end{array}$ & $\begin{array}{l}1.13 \pm \\
0.02 *\end{array}$ & $\begin{array}{l}0.111 \pm \\
0.002 *\end{array}$ & $\begin{array}{c}80.44 \pm \\
0.06 *\end{array}$ \\
\hline \multicolumn{2}{|c|}{ Follow-up control } & $\begin{array}{c}0.152 \pm \\
0.008\end{array}$ & $\begin{array}{l}1.52 \pm \\
0.08\end{array}$ & $\begin{array}{c}0.069 \pm \\
0.005\end{array}$ & $\begin{array}{c}45.43 \pm \\
0.04\end{array}$ & $\begin{array}{c}0.181 \pm \\
0.012\end{array}$ & $\begin{array}{c}1.81 \pm \\
0.12\end{array}$ & $\begin{array}{c}0.088 \pm \\
0.008\end{array}$ & $\begin{array}{l}78.53 \pm \\
0.07 *\end{array}$ \\
\hline
\end{tabular}

Notes. * - $p<0.05$ - statistically significant difference between the indices in apparently healthy people of the control group and other studied patients.

$R A$ - rheumatoid arthritis;

SSc - systemic sclerosis;

SLE - systemic lupus erythematosus.

Table 3. Average density of skin hemocapillaries of the patients per $1 \mathrm{~mm}^{2}$

\begin{tabular}{|c|c|c|}
\hline Groups & $\begin{array}{c}\text { No peripheral blood circulation } \\
\text { disorders } \\
\text { (group1, } \mathrm{n}=11)\end{array}$ & $\begin{array}{c}\text { Peripheral blood circulation } \\
\text { disorders } \\
\text { (group } 2, \mathrm{n}=15 \text { ) }\end{array}$ \\
\hline Normal range & $43.0 \pm 1.9$ & - \\
\hline $\begin{array}{l}\text { Rheumatoid arthritis, } \\
n=8\end{array}$ & $\begin{array}{l}40.0 \pm 1.8 \\
p 1>0.05\end{array}$ & $\begin{array}{l}37.0 \pm 1.6 \\
p^{1}>0.05 \\
p^{2}>0.05\end{array}$ \\
\hline $\begin{array}{l}\text { Systemic sclerosis, } \\
\mathrm{n}=8\end{array}$ & $\begin{array}{l}38.0 \pm 1.7 \\
p 1>0.05\end{array}$ & $\begin{array}{l}21.0 \pm 1.0 \\
\mathrm{p}^{1}<0.01 \\
\mathrm{p}^{2}<0.01\end{array}$ \\
\hline $\begin{array}{l}\text { Systemic lupus erythematosus, } \\
\qquad n=10\end{array}$ & $\begin{array}{l}41.0 \pm 1.9 \\
p 1>0.05\end{array}$ & $\begin{array}{l}36.0 \pm 1.7 \\
p^{1}<0.05 \\
p^{2}>0.05\end{array}$ \\
\hline
\end{tabular}

Notes:

$p^{1}$ - statistically significant difference between the normal range and average density of hemocapillaries per unit area in patients of both groups;

$p^{2}$ - statistically significant difference between the indices in patients of the groups 1 and 2 .

At the same time, concentration of ET- 1 in the patients without vessel disorders is not substantially different from normal range.
Discussion

Among the examinees, the detection rate of peripheral hemodynamic disorders in the 
Table 4. Distribution of skin hemocapillaries of the patients over the duct width

\begin{tabular}{|c|c|c|c|c|c|c|}
\hline \multirow{3}{*}{ Disease } & \multicolumn{3}{|c|}{$\begin{array}{l}\text { No peripheral blood circulation disorders } \\
\text { (group 1, } \mathrm{n}=11)\end{array}$} & \multicolumn{3}{|c|}{$\begin{array}{l}\text { Peripheral blood circulation disorders } \\
\text { (group 2, } \mathrm{n}=15 \text { ) }\end{array}$} \\
\hline & \multicolumn{3}{|c|}{$\begin{array}{c}\text { The number of hemocapillaries } \\
\text { and their diameter }\end{array}$} & \multicolumn{3}{|c|}{$\begin{array}{c}\text { The number of hemocapillaries } \\
\text { and their diameter }\end{array}$} \\
\hline & $8-12 \mu \mathrm{m}$ & $15-25 \mu \mathrm{m}$ & $\begin{array}{l}\text { above } \\
25 \mu \mathrm{m}\end{array}$ & 8-12 $\mu \mathrm{m}$ & $15-25 \mu \mathrm{m}$ & $\begin{array}{l}\text { above } \\
25 \mu \mathrm{m}\end{array}$ \\
\hline Normal range & 100 & - & - & 100 & - & - \\
\hline $\begin{array}{l}\text { Rheumatoid } \\
\text { arthritis, } \\
\mathrm{n}=8\end{array}$ & $\begin{array}{c}80.6 \pm 3.6 \\
p^{1}<0.01\end{array}$ & $12.1 \pm 0.6$ & $7.3 \pm 0.3$ & $\begin{array}{l}31.3 \pm 1.5 \\
p^{1}<0.01 \\
p^{2}<0.01\end{array}$ & $46.6 \pm 2.2$ & $22.1 \pm 1.0$ \\
\hline $\begin{array}{l}\text { Systemic } \\
\text { sclerosis, } \\
n=8\end{array}$ & $\begin{array}{l}71.7 \pm 3.3 \\
p^{1}<0.01\end{array}$ & $24.5 \pm 1.1$ & $3.82 \pm 0.17$ & $\begin{array}{l}8.0 \pm 0.3 \\
p^{1}<0.01 \\
p^{2}<0.01\end{array}$ & $58.9 \pm 2.8$ & $33.1 \pm 1.5$ \\
\hline $\begin{array}{l}\text { Systemic lupus } \\
\text { erythematosus, } \\
n=10\end{array}$ & $\begin{array}{c}69.2 \pm 3.3 \\
p^{1}<0.01\end{array}$ & $29.7 \pm 1.4$ & $1.13 \pm 0.04$ & $\begin{array}{l}7.5 \pm 0.3 \\
p^{1}<0.01 \\
p^{2}<0.01\end{array}$ & $43.2 \pm 2.0$ & $49.3 \pm 2.4$ \\
\hline
\end{tabular}

\section{Notes:}

$p^{1}$ - statistically significant difference between the normal range and the number of normal-sized capillaries (8-12 $\mu m$ ) in the patients of both groups;

$p^{2}$ - statistically significant difference between the number of capillaries 8-12 $\mu \mathrm{m}$ in diameter in the patients of the groups 1 and 2 .

patients with RA was $75.6 \%$, which is slightly higher than the established results of statistical researches. Peripheral blood circulation disorders were diagnosed in the patients with SLE in $80 \%$ of cases, in the patients with SSC - in $97.4 \%$ of cases, which is consistent with literature $[10,11]$.

Despite nearly equal distribution of patients in every group by age, duration of a disease, activity of the inflammatory process, it has been revealed that a kidney, lung or heart are damaged more frequently in the patients with peripheral blood circulation disorders. Such results are probably associated with the development of systematicity, which is caused by peripheral blood flow and microcirculation disorders.

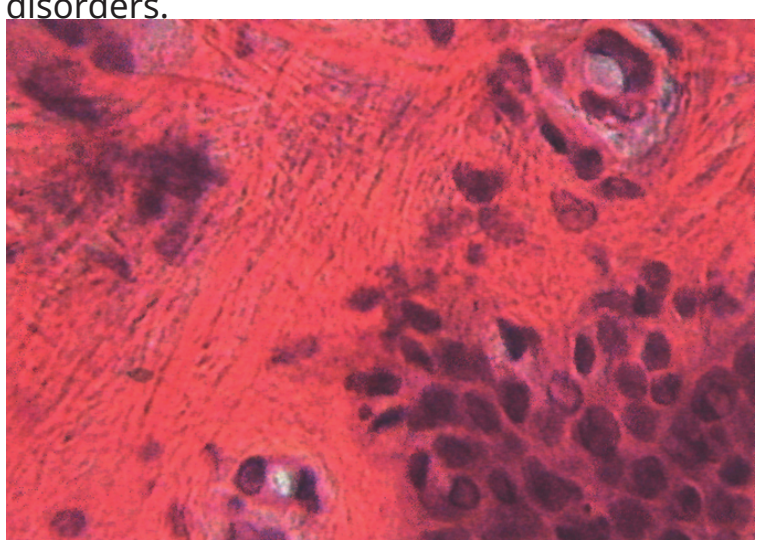

Figure 1. Biopsy material of skin flaps harvested from the finger of the patient $F$. with rheumatoid arthritis, medical record of the in-patient patient No. 01/10064. Staining H\&E. $\times 600$

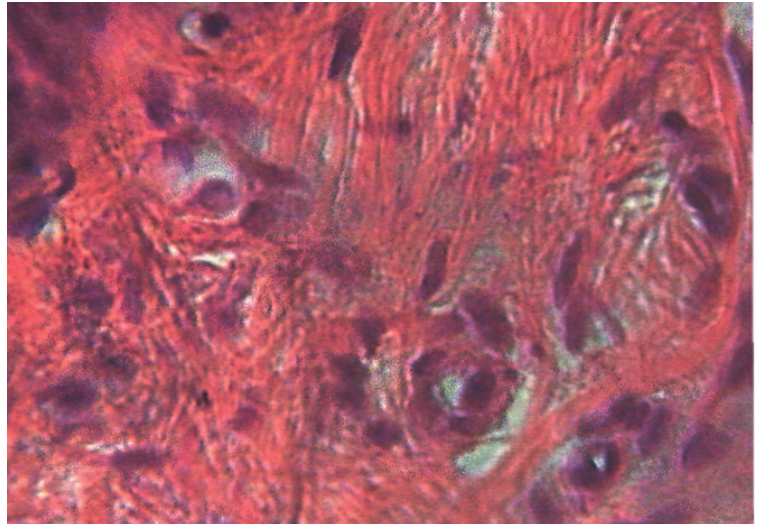

Figure 2. Biopsy material of skin flaps harvested from the finger of the patient Sh. with systemic lupus erythematosus, medical record of the in-patient patient No. 01/00920. Staining H\&E. ×600

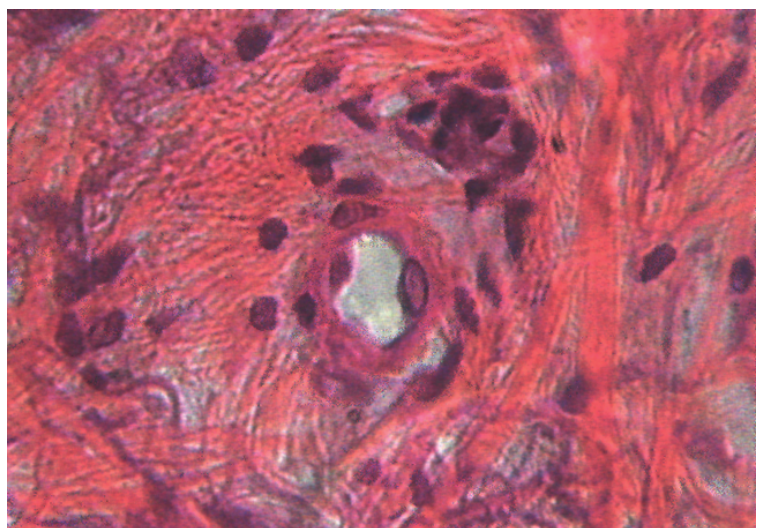

Figure 3. Biopsy material of skin flaps harvested from the finger of the patient Kh. with systemic sclerosis, medical record of the in-patient patient No. 01/07587. Staining H\&E. $\times 600$ 
Table 5. Concentration of ET1 in the patients with rheumatic diseases with/without peripheral blood circulation disorders

\begin{tabular}{|c|c|c|}
\hline \multicolumn{2}{|c|}{ Group of patients } & ET1, pkg/ml \\
\hline \multicolumn{2}{|c|}{ Donors, $\mathrm{n}=10$} & $1.8 \pm 0.7$ \\
\hline \multicolumn{2}{|c|}{ Group 1, n=5 } & $\begin{array}{l}1.9 \pm 0.5 \\
p^{1}>0.05 \\
\end{array}$ \\
\hline \multirow[t]{3}{*}{ Group 2} & SLE, $n=10$ & $\begin{array}{l}19.0 \pm 1.4 \\
p^{1}<0.001 \\
p^{2}<0.001\end{array}$ \\
\hline & SSc, $n=10$ & $\begin{array}{l}23.1 \pm 1.5 \\
p^{1}<0.001 \\
p^{2}<0.001\end{array}$ \\
\hline & $R A, n=10$ & $\begin{array}{l}18.9 \pm 1.4 \\
p^{1}<0.001 \\
p^{2}<0.001\end{array}$ \\
\hline
\end{tabular}

Notes:

$p^{1}$ - statistically significant difference between indices in patients and donors;

$p^{2}$ - statistically significant difference between indices in $p a-$ tients of the groups 1 and 2.

$R A$ - rheumatoid arthritis; SSC - systemic sclerosis; SLE - systemic lupus erythematosus.

In the rheograms of the patients with peripheral blood circulation disorders the height of percussion wave and RI decrease is related to the increase in duration of the disease. Thus, RI in the forearms of the patients, who suffer from the disease for a period of less than 1 year, decreased by $19.07 \%$. At the same time, the systolic blood flow in the forearms of the patients, who suffer for 10 or more years, decreased by $44.08 \%$. Meanwhile, DI value points to hypertonia of precapillary vessels in all investigated groups, but this indice is statistically lower $(p<0,001)$ among the patients, who suffer for a period of less than 1 year, and increases if the duration of the disease is longer.

In the patients divided by the nosological units, the lowest rates of systolic flow were observed in patients with SSc, meanwhile, RI decreased by $46.05 \%$; the patients with RA and a deficit in RI, representing $41.45 \%$, were the second; consequently, the smallest changes in RI were found in the patients with SLE, whose systolic blood flow in forearms decreased by $28.29 \%$. The tonus of precapillary vessels, which was significantly higher in the patients with SSC $(p<0.001)$, was changed compare to the abovementioned data.

Analysis of rheovasography indices in terms of the degrees of inflammatory process activity (which was determined by the erythrocyte sedimentation rate) revealed no statistically significant difference. However, at the highest degree of the inflammatory process activity DI was of the smallest value and significantly different $(p<0.001)$ from the indices at the $1^{\text {st }}$ and $2^{\text {nd }}$ degrees of activity.

Thus, the most significant peripheral blood circulation disorders were found in the patients with SSc $(p<0.05)$; disorders of peripheral blood flow were exacerbated in case of lengthening of disease course. Hypertonia of peripheral vessels and decrease in systolic blood flow were reflected in flattening of a rheographic curve and rheographic index decrease. Hypertonia of arterioles and precapillary vessels was evident by high location of incisures in relation to the apex of the rheographic curve and a high DI value.

The analysis of morphometric data revealed that the average density of capillaries per unit area statistically decreased only in the patients with peripheral blood flow disorders in cases of SLE and SSC.

Along with the decrease in the number of normal-sized capillaries, dilated and megacapillaries were present. Meanwhile, their number was small in the patients without peripheral blood flow disorders and statistically significant in the patients with hemodynamic disorders. In terms of relative values, the number of pathologic capillaries was $66.7 \%$ in cases of RA, $92.0 \%$ in cases of SSc and $91.5 \%$ in cases of SLE.

The concentration of ET-1 was significantly higher in the patients with peripheral blood flow disorders. To examine the changes in concentration of ET-1 in detail, all the patients with the signs of vascular bed damage were divided into three groups by the degree of the inflammatory process activity. The revealed changes were reflected in gradual increase in concentration of ET-1 in case of a higher degree of inflammatory process activity, though there was no statistically significant difference between the indices.

According to the results of our study it has been established that microcirculatory bed changes in the patient with SSC and SLE complied with other literature regarding investigation of non-invasive methods of studying of microcirculatory bloodstream such as nailfold videocapillaroscopy $[5,6,7]$. Minimal changes have been revealed in the patients with RA [5].

\section{Conclusions}

It should be noted that peripheral hemodynamic disorders are followed by significant microcirculatory bloodstream disorders such as decrease in average density of hemocapillaries per unit area, decrease in the number of nor- 
mal-sized capillaries, and increase in the number of dilated and megacapillaries. Morphometric changes are accompanied by endothelial dysfunction with a high concentration of ET-1. In terms of integral estimation extremely high level of changes is evidenced in the patients with SSc which complies with current understanding of this disease.

However, some morphometric peculiarities were revealed in the patients without peripheral blood flow disorders: in cases of adequate density of hemocapillaries per unit area, there was a decrease in the number of normal-sized capillaries and presence of dilated and megacapillaries. The above-mentioned changes were not followed by endothelial dysfunction in relation to ET1 indicator. Thus, normal rheovasography did not preclude the presence of microcirculation disorders since biopsy revealed deeper changes in microcirculatory bed.
The further research should be focused on the search for non-invasive methods of studying microcirculatory bloodstream in the patients with rheumatic diseases, which is the main cause of the development of systematicity.

Acknowledgements: The authors are gratefully acknowledged to Mariana Karanevych (PhD in Philology, Associate Professor) with the help in translation of this article.

Funding

This research received no external funding. Conflict of Interests

The authors declare no conflict of interest. Author Contributions

Zarudna O.I. - conceptualization, data curation, formal analysis, investigation, writing original draft and review \& editing; Venher I.K. conceptualization, data curation, validation, methodology; Dovbush A.V. - formal analysis, investigation, visualization, software.

\section{СИСТЕМНІ ЗАХВОРЮВАННЯ СПОЛУЧНОЇ ТКАНИНИ: ФОКУС НА МІКРОЦИРКУЛЯТОРНЕ РУСЛО}

О.І. Зарудна, І.К. Венгер, А.В. Довбуш

ТЕРНОПІЛЬСЬКИЙ НАЦІОНАЛЬНИЙ МЕДИЧНИЙ УНІВЕРСИТЕТ ІМЕНІ І.Я. ГОРБАЧЕВСЬКОГО, ТЕРНОПІЛЬ,

УКРАЇНA

Вступ. Прояви системних захворювань є надзвичайно різноманітними. Їх об'єднує наявність васкуліту/васкулопатії, що й зумовлює системність і приводить до розвитку стійких порущень функції органів і систем. При цьому мішенню, джерелом та причиною патологічного процесу $\epsilon$ ендотелій.

Мета. Провести комплексне вивчення стану мікроциркуляторного русла у хворих на системний червоний вовчак (СЧВ), системну склеродермію (ССД) та ревматоїдний артрит (РА).

Методи. Для досягнення мети проведено ретроспективний аналіз архівних історій хвороби 129 хворих на ревматичні захворювання, з них 39 - з верифікованим діагнозом ССД, 54 - СЧВ та 45 - РА. Переглянуто архів біоптатів шкірного клаптя пальця пацієнтів, на основі чого проведено морфометричний аналіз. Стан периферичної гемодинаміки вивчали за результатами поздовжньої реовазографії передпліч та гомілок. Вміст ЕT - 1 визначено за імуноферментною методикою, яка ґрунтується на принципі конкурентного імуноферментного аналізу. Клінічні та лабораторні дані співставлень з результатами морфологічного дослідження біоптатів.

Результати. У переважної більшості пацієнтів виявлено розлади периферичної гемодинаміки. Встановлено, що ураження нирок, легень, серця частіше спостерігається у хворих з розладами периферичного кровоплину, проте найглибші порушення виявлено у хворих на системну склеродермію $(p<0,05)$. Порушення периферичної гемодинаміки супроводжуються підвищенням концентрації ендотеліну-1 та поглиблюються за умови зростання тривалості хвороби. Кількість патологічних капілярів найвища у хворих на системну склеродермію.

Висновки. Крайній ступінь розладів мікроциркуляторного русла за інтегральною оцінкою клініколабораторних та морфометричних досліджень виявлено у пацієнтів на ССД. Однак знайдено деякі морфологічні особливості у пацієнтів без розладів периферичного кровоплину. Отже відсутність патологічних відхилень за результатами реовазографії не виключає розладів на мікроциркуляторному рівні.

КЛЮЧОВІ СЛОВА: мікроциркуляція; системний червоний вовчак (СчВ), системна склеродермія (ССД), ревматоїдний артрит (РА); біопсія; реовазографія. 


\section{Інформація про авторів}

Зарудна Ольга Ігорівна - канд. мед. наук, доцент кафедри клінічної імунології, алергології та загального догляду за хворими, Тернопільський національний медичний університет імені I.Я. Горбачевського.

Венгер Ігор Касянович - доктор медичних наук, професор, завідувач кафедри хірургії №2, Тернопільський національний медичний університет імені І.Я. Горбачевського.

Довбуш Андрій Васильович - канд. біол. наук, доцент кафедри гістології та ембріології, Тернопільський національний медичний університет імені І.Я. Горбачевського.

\section{Information about the authors}

Olga I. Zarudna - MD, Ph.D., Associate Professor, Department of Clinical Immunology, Allergology and General Patients' Care, I. Horbachevsky Ternopil National Medical University.

ORCID 0000-0002-9374-3991, e-mail: zarudna@tdmu.edu.ua

Ihor K. Venher - MD, Ph.D., DSc, Professor, Head of the Department of Surgery No. 2, I. Horbachevsky Ternopil National Medical University.

ORCID 0000-0003-0170-1995, e-mail:vengerik@tdmu.edu.ua

Andriy V. Dovbush - Ph.D., Associate Professor, Department of Histology and Embryology, I. Horbachevsky Ternopil National Medical University.

ORCID 0000-0003-2246-6218, e-mail: dovbush@tdmu.edu.ua

\section{References}

1. Bărbulescu AL, Vreju AF, Bugă AM, Sandu RE, Criveanu C, Tudoraşcu DR, Gheonea IA, Ciurea PL. Vascular endothelial growth factor in systemic lupus erythematosus-correlations with disease activity and nailfold capillaroscopy changes. Rom J Morphol Embryol. 2015 Jan 1;56(3):1011-6.

2. Kuryliszyn-Moskal A, Klimiuk PA, Sierakowski S, Ciolkiewicz M. Vascular endothelial growth factor in systemic lupus erythematosus: relationship to disease activity, systemic organ manifestation, and nailfold capillaroscopic abnormalities. Arch. Immunol. Ther. Exp. 2007;55:179-85.

doi: $10.1007 / \mathrm{s} 00005-007-0017-7$

3. Kuryliszyn-Moskal A, Klimiuk PA, Sierakowski S, Ciolkiewicz M. A study on vascular endothelial growth factor and endothelin-1 in patients with extraarticular involvement of rheumatoid arthritis. Clinical Rheumatology. 2006; 25(3):314-9.

doi: 10.1007/s10067-005-0007-2

4. Maurizio Cutolo M, Sulli A, Smith V. Assessing Microvascular Changes in Systemic Sclerosis Diagnosis and Management. Nat Rev Rheumatol. 2010;6(10):578-87.

doi: 10.1038/nrrheum.2010.104

5. Mihail C, Tervaert JWC. Anti-endothelial cell antibodies in systemic sclerosis. BMJ journals Annals of Rheumatic Diseases.2010;69(2):319-24.

doi: 10.1136/ard.2008.102400

6. Chojnowski MM, Felis-Giemza A, Olesinska M. Capillaroscopy - a role in modern rheumatology. Reumatologia. 2016;54(2):67-72.

doi: 10.5114/reum.2016.60215

7. Ragab O, Ashmawy A, Abdo M, Mokbel A. Nailfold capilloroscopy in systemic lupus erythe- matosus. The Egyptian Rheumatologist. 2011; 33(1):61-7.

doi: 10.1016/j.ejr.2010.12.003

8. Etehad Tavakol M, Fatemi A, Karbalaie A, Emrani Z, Erlandsson BE. Nailfold capillaroscopy in rheumatic diseases: which parameters should be evaluated? BioMed research international, 2015. Article ID 974530. 17 pages.

doi: $10.1155 / 2015 / 974530$

9. Ciolkiewicz M, Kuryliszyn-Moskal A, Klimiuk PA. Analysis of correlations between selected endothelial cell activation markers, disease activity, and nailfold capillaroscopy microvascular changes in systemic lupus erythematosus patients. Clin Rheumatol. 2010;29(2):175-80.

doi: 10.1007/s10067-009-1308-7

10. Dimitrijevic J, Brajuckovic G, Cerovic S, Popovic Z, Bogdanovic R, Jovanovic D, et al. Morphology of autoimmune diseases. Arch oncol. 2004;12:27-9.

https://pdfs.semanticscholar.org/a10f/9bc9613 9a020f252e49f80d9d65be4b72e24.pdf

11. Holovach IYu, Egudina ED. Systemic scleroderma: modern view on pathogenesis, course, diagnosis and treatment. Semeynaya Meditsina. 2019;3:7-16. http://nbuv.gov.ua/UJRN/simmed_2019_3_3. (In Russian).

12. Sinyachenko OV, Egudina ED, Khaniukov AA, Ermolaeva MB, Gulmamedova MF, Potapov YuA. Specific course of angiopathy in systemic autoimmune rheumatic diseases. 2017;2:33-9.

http://nbuv.gov.ua/UJRN/UTJ_2017_2_7.

Received 03 July 2019; revised 03 October 2019; accepted 23 October 2019.

This is open access article distributed under the Creative Commons Attribution License, which permits unrestricted use, distribution, and reproduction in any medium, provided the original work is properly cited. 